\title{
Pengaruh Debt Covenant, Ukuran Perusahaan, Profitabilitas, Likuiditas, Dan Leverage Terhadap Konservatisme Akuntansi (Pada perusahaan sektor Aneka Industri Yang Terdaftar di Bursa Efek Indonesia Tahun 2016-2019) Suhaeni ${ }^{1}$, Mohamad Zulman Hakim ${ }^{2}$, Dirvi Surya Abbas ${ }^{3}$ \\ Universitas Muhammadiyah Tangerang ${ }^{1,2,3}$ Koresponden Email : henii.suhaeni158@gmail.com
}

\begin{abstract}
Abstrak: Konservatisme akuntansi merupakan variabel dependen dalam penelitian ini yang diukur dengan akrual non operasional. Variabel independen dalam penelitian ini adalah debt covenant, ukuran perusahaan, profitabilitas, likuiditas dan leverage. Sampel dalam penelitian ini adalah perusahaan pada sektor aneka industry yang terdaftar di Bursa Efeklndonesia pada tahun 2016-2019. Sampel dikumpulkan dengan menggunakan metode purposive sampling dan menghasilkan 32 perusahaan menjadi sampel. Analisis data dilakukan dengan pengujian hipotesis dengan melakukan metode regresi linier berganda menggunakan EVIEWS 9. Penelitian ini menyimpulkan bahwa Debt Covenant, Ukuran Perusahaan berpengaruh negative terhadap konservatisme akuntansi. Namun Profitabilitas, likuiditas dan leverage tidak berdampak positif terhadap konservatisme akuntansi.
\end{abstract}

Kata kunci: Debt Covenant, ukuran perusahaan, profitabilitas, likuiditas, leverage, konservatisme akuntansi.

Persaingan global menjadi tantangan tak terelakkan bagi perusahaan di Indonesia. Hal ini disebabkan banyaknya perusahaan yang diperbolehkan masuk secara cuma-cuma di Indonesia. Namun, tidak semua perusahaan di Indonesia siap untuk menghadapi persaingan global ini. Salah satu akibatnya adalah kurangnya kesadaran perusahaan untuk mempergunakan standar International Financial Reporting Standar (IFRS). Tujuan perusahaan diwajibkan menerapkan standar IFRS ini adalah untuk penyetaraan laporan keuangan seluruh perusahaan di Indonesia dengan di dunia. Laporan keuangan adalah sebuah hasil operasional sebuah perusahaan dalam satu periode.

Watts (2003) mendefinisikan konservatisme sebagai perbedaan permintaan verifibilitas dalam mengakui laba atau kerugian. Konservatisme merupakan prinsip akuntansi yang penerapannya akan menyebabkan angka laba dan aset menjadi rendah dan biaya serta hutang menjadi tinggi. Konservatisme merupakan konsep akuntansi yang kontroversial, banyak pertentangan tentang penggunaan konservatisme dalam penyusunan laporan keuangan. Penggunaan konservatisme dapat dianggap bermanfaat yaitu untuk mengantisipasi ketidakpastian yang dapat dialami perusahaan di masa mendatang, namun di sisi lain penggunaan konservatisme dianggap tidak mencerminkan kondisi keuangan perusahaan yang sebenarnya sehingga dapat mempengaruhi kualitas laporan keuangan perusahaan. Contoh kecurangan tersebut adalah manipulasi laporan keuangan yang dilakukan oleh PT.Kimia Farma yang telah melakukan manipulasi laporan keuangan yaitu dengan adanya 
penggelembungan laba bersih tahunan senilai $\mathrm{Rp} 32,668$ miliar yaitu pada laporan keuangan yang seharusnya adalah $\mathrm{Rp} 99,594$ miliar namun ditulis Rp 132 miliar. Laba bersih yang overstate tersebut terjadi karena adanya kesalahan penilaian persediaan barang jadi dan kesalahan pencatatan penjualan (Bapepam, 2002). Hal tersebut dapat didefinisikian bahwa prinsip konservatisme yang diterapkan perusahaan tersebut dalam penyusunan laporan adalah rendah. Oleh sebab itu terjadi penggelembungan laba pada laporan keuangan perusahaan tersebut.

Berdasarkan latar belakang dan hasil penelitian terdahulu yang berbeda-beda, maka penelitian ini dilakukan bertujuan untuk mengetahui secara empiris bagaimana pengaruh debt covenant, ukuran perusahaan, profitabilitas, likuiditas, dan leverage terhadap konservatisme akuntansi.

Tabel 1. Kerangka Konseptual

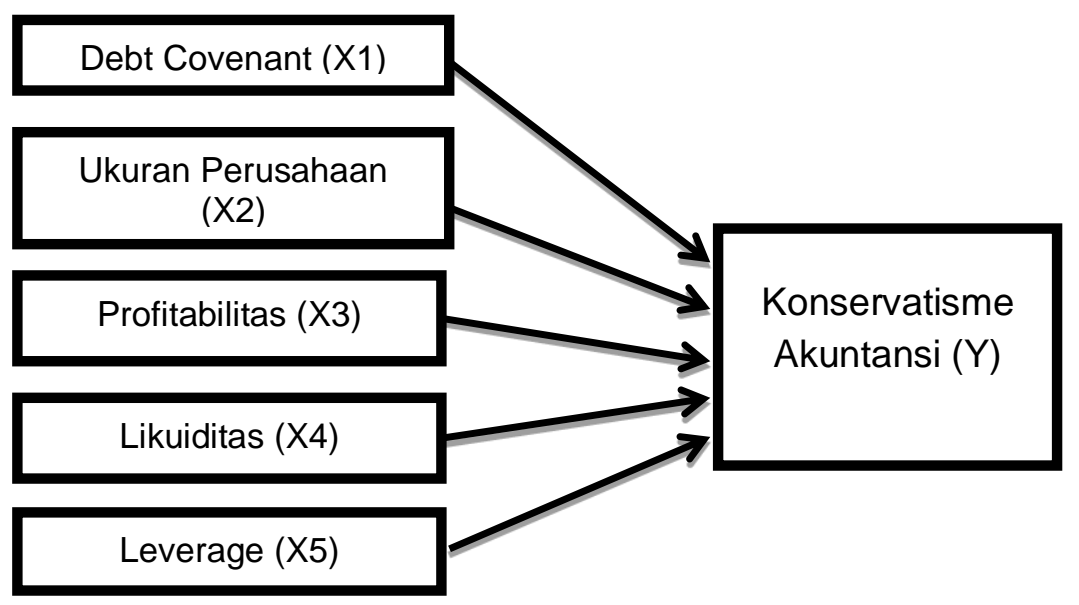

\section{METODE}

Penelitian ini merupakan penelitian kuantitatif dengan menggunakan regresi linier berganda dengan data penelitian menggunakan data sekunder. Data sekunder dalam penelitian ini adalah laporan keuangan tahunan perusahaan sektor Aneka Industri yang terdapat di Bursa Efek Indonesia (BEI) dari tahun 2016 dan tahun 2019. Pengambilan sampel dengan menggunakan purposive sampling dengan kriteria perusahaan yang menerbitkan laporan keuangan auditan tahun 2016 - 2019, perusahaan yang menyajikan laporan keuangan dalam mata uang rupiah dan memiliki data yang lengkap terkait dengan variabelvariabel yang digunakan dalam penelitian.Populasi penelitian ini adalah seluruh perusahaan yang terdaftar di Bursa Efek Indonesia dengan sampel perusahaan pada sektor aneka industry. Teknik pengambilan sampel menggunakan metode purposive sampling, dengan data perusahaan yang memiliki kriteria sebagai berikut: 
Tabel 2. Kriteria sample data

$\begin{array}{ll}\text { Keterangan } & \text { Jumlah } \\ \begin{array}{l}\text { Perusahaan Sektor Aneka Industri yang } \\ \text { listing di BEI tahun 2016-2019 }\end{array} & 44 \\ \begin{array}{l}\text { Perusahaan yang tidak melaporkan Laporan } \\ \text { Keuangan selama periode } 2016-2019\end{array} & (8) \\ \begin{array}{l}\text { Tahun pengamatan 2016-2019 } \\ \text { Jumlah observasi total periode penelitian }\end{array} & 8 \\ \text { X 4) } & 32\end{array}$

Konservatisme Akuntansi $(\mathrm{Y})$

Konservatisme Akuntansi, yang merupakan sebuah prinsip perusahaan berhati-hati dalam menentukan setiap nilai yang ada dilaporan keuangan, sehingga nilai yang ada di pos-pos keuangan memiliki nilai yang bisa dipertanggungjawabkan. Konservatisme dalam penelitian ini diukur dengan menggunakan market to book (Agustina et al.,2015), yaitu:

$$
\text { Market to Book }=\frac{\text { Harga pasar per saham }}{\text { Nilai Buku per saham }}
$$

Nilai Buku per Saham $=\frac{\text { Total Ekuitas }}{\text { Jumlah saham Beredar }}$

\section{Debt Covenant (X1)}

Debt Covenant adalah kontrak hutang yang bertujuan menganalisis pembelanjaan yang dilakukan perusahaan untuk melunasi utang serta kemampuan perusahaan membayar bunga dan beban. Pengukuran debt covenant dapat dirumuskan sebagai berikut:

$$
D C=\frac{\text { Total Hutang }}{\text { Total Aset }}
$$

\section{Ukuran Perusahaan (X2)}

Ukuran perusahaan merupakan ukuran yang digunakan untuk mengukur perusahaan dari seberapa luas pengungkapan informasi. Penelitian ini menggunakan pengukuran perusahaan dengan rumus sebagai berikut:

$$
\text { Size = Log Natural }(\text { Total Aset })
$$

Profitabilitas (X3)

Profitabilitas adalah kemampuan perusahaan dalam menghasilkan laba melalui semua kemampuan dan sumber daya yang ada. Pada penelitian ini profitabilitas diproksikan dengan Return On Asset (ROA). ROA dapat dihitung menggunakan (Brigham, 2006):

$$
\text { ROA }=\frac{\text { Laba Bersih }}{\text { Total Aktiva }} \times 100 \%
$$


Likuiditas (X4)

Rasio likuiditas antara lain dapat dihitung dengan: Current Ratio, Cash Ratio, dan Quick Ratio. Semakin tinggi rasio ini semakin baik, karena berarti aktiva lancar yang digunakan untuk membayar hutang lancar semakin besar. Pada penelitian ini likuiditas diproksikan dengan current ratio.

$$
\text { Likuiditas }=\frac{\text { Aset Lancar }}{\text { Utang Lancar }}
$$

Leverage (X5)

Leverage merupakan rasio yang menunjukkan seberapa besar utang atau modal membiayai aktiva perusahaan (Noviantari dan Ratnadi, 2015). Leverage dihitung dengan melihat proposi besarnya aset yang dibiayai oleh hutang.

$$
\text { Leverage }=\frac{\text { Total Hutang }}{\text { Total Modal }}
$$

Dalam penelitian ini, teknik analisis data yang digunakan adalah analisis regresi data panel dengan bantuan sofware pengolah data statistik yaitu Eviews 9.0. Adapun metode analisis data yang digunakan dalam penelitian ini terdiri dari:

1. Analisis Statistik Deskriptif

Statistik deskriptif biasanya digunakan oleh peneliti untuk memberikan informasi mengenai karakteristik variabel penelitian yang utama (Alpiah, 2018). Deskripsi data statistik terdiri dari mean, median, maximum, minimum, standard deviation, skewness, kurtosis, Jarque-Bera, dan probability (Winarno, 2015).

7. Estimasi Regresi Data Panel Model Regresi Data Panel terbagi menjadi 3 model yaitu common effects, fixed effects, dan random effects.

8. Teknik Pemilihan Model Regresi Data Panel

Teknik Pemilihan Model Regresi Data Panel terbagi menjadi 3 model yaitu uji chow, uji hausman, dan uji lagrange multiplier.

d. Uji Chow

Hipotesis dalam Chow Test adalah sebagai berikut:

$\mathrm{HO}$ : Model mengikuti common effect

$\mathrm{Ha}$ : Model mengikuti fixed effect

e. Uji Hausman

Hipotesis dalam Hausman test adalah sebagai berikut:

$\mathrm{HO}$ : Model mengikuti random effect

$\mathrm{Ha}$ : Model mengikuti fixed effect

f. Uji Lagrange Multiplier

Hipotesis dalam Lagrange Multiplier test adalah sebagai berikut:

$\mathrm{HO}$ : Model mengikuti common effect 
$\mathrm{Ha}$ : Model mengikuti random effect

9. Uji Asumsi Klasik

Diperlukan Uji Asumsi Klasik apabila model regresi yang digunakan dalam bentuk Common Effects Model atau Fixed Effects Model. Sebaliknya apabila persamaan regresi lebih cocok menggunakan Random Effects Model maka tidak perlu dilakukan uji asumsi klasik. Uji Asumsi Klasik terdiri dari uji Linieritas, Autokorelasi, Multikolineritas, Normalitas, dan Heteroskedastisitas. Walaupun demikian tidak semua uji dilakukan dalam regresi data panel, hanya uji Multikolineritas dan Heteroskedastisitas saja yang diperlukan.

10. Uji Hipotesis

Terdapat tiga jenis uji hipotesis yaitu sebagai berikut:

d. Uji F

Adapun hipotesis dalam uji $\mathrm{F}$ adalah sebagai berikut:

Berdasarkan perbandingan F-statistic dengan $\mathrm{F}$ tabel

$\mathrm{HO}$ : Jika nilai F-statistic $<\mathrm{F}$ Tabel

$\mathrm{Ha}$ : Jika nilai F-statistic $>\mathrm{F}$ table Berdasarkan Probabilitas

$\mathrm{HO}$ : Jika nilai prob (F-statistic) $>\alpha 0,05$

$\mathrm{Ha}$ : Jika nilai prob (F-statistic) $<$ a 0,05

e. Uji Koefisien Determinasi

Nilai R-squared berada antara 0 sampai 1 dengan penjelasan sebagai berikut:

i. $\quad$ Nilai R-squared harus berkisar 0 sampai 1

ii. Jika nilai R-squared sama dengan 1 , berarti naik atau turunnya variabel terikat $(Y) 100 \%$ dipengaruhi oleh variabel bebas $(X)$

iii. Jika nilai $R$-squared sama dengan 0 , berarti tidak ada hubungan sama sekali antara variabel independen dengan

f. Uji T variabel dependen.

Hipotesis dalam uji T adalah sebagai berikut:

Berdasarkan perbandingan T-statistic dengan Ttabel

$\mathrm{HO}$ : Jika nilai T-statistic $<\mathrm{T}$ Tabel

$\mathrm{Ha}$ : Jika nilai T-statistic $>\mathrm{T}$ tabel

Berdasarkan Probabilitas

$\mathrm{HO}$ : Jika nilai prob (T-statistic) $>\alpha 0,05$

$\mathrm{Ha}$ : Jika nilai prob (T-statistic) $<\alpha 0,05$

11. Analisis Regresi Data Panel

Regresi data panel adalah gabungan antara data cross section (data beberapa perusahaan) dan data time series (data yang dihimpun lebih dari satu tahun), dimana unit cross section yang sama diukur pada waktu yang berbeda. Maka dengan kata lain data panel merupakan data dari beberapa perusahaan (sampel) yang diamati dalam beberapa kurun waktu tertentu. 
HASIL

Analisis Statistik Deskriptif

Tabel 3. Analisi Statistik Deskriptif

\begin{tabular}{|c|c|c|c|c|c|c|}
\hline & KA & DEBT & SIZE & ROA & LIK & LEVE \\
\hline Mean & 0.277313 & 0.413219 & 28.26931 & 0.069469 & 2.365281 & 0.859781 \\
\hline Median & 0.296500 & 0.411500 & 28.28250 & 0.043000 & 1.775000 & 0.700000 \\
\hline Maximum & 0.757000 & 0.831000 & 30.40500 & 0.227000 & 5.828000 & 2.522000 \\
\hline Minimum & 0.041000 & 0.092000 & 26.68400 & 0.012000 & 1.061000 & 0.102000 \\
\hline Std. Dev. & 0.194822 & 0.198613 & 1.009081 & 0.061460 & 1.367287 & 0.668640 \\
\hline Skewness & 0.579594 & 0.194183 & 0.677326 & 1.837738 & 1.209793 & 0.965710 \\
\hline Kurtosis & 2.529585 & 2.040199 & 3.115767 & 5.039357 & 3.153526 & 2.974099 \\
\hline \begin{tabular}{|l} 
Jarque- \\
Bera \\
\end{tabular} & 2.086673 & 1.429394 & 2.464648 & 23.55748 & 7.837286 & 4.974742 \\
\hline Probability & 0.352277 & 0.489340 & 0.291614 & 0.000008 & 0.019868 & 0.083128 \\
\hline Sum & 8.874000 & 13.22300 & 904.6180 & 2.223000 & 75.68900 & 27.51300 \\
\hline $\begin{array}{ll}\text { Sum } & \text { Sq. } \\
\text { Dev. }\end{array}$ & 1.176627 & 1.222863 & 31.56556 & 0.117096 & 57.95371 & 13.85948 \\
\hline $\begin{array}{l}\text { Observation } \\
\text { s }\end{array}$ & 32 & 32 & 32 & 32 & 32 & 32 \\
\hline
\end{tabular}

Sumber. data diolah, 2020

Pada tabel diatas, dapat dijelaskan bahwa jumlah data (observations) yang digunakan dalam penelitian ini sebanyak 32 data.

Nilai Mean terbesar dialami oleh variabel Ukuran Perusahaan (SIZE) yaitu sebesar 28, 26931, sementara Profitabilitas (ROA) memiliki nilai mean terkecil yaitu 0,069469. Median terbesar dialami oleh variabel Ukuran Perusahaan (SIZE) yaitu sebesar 28,28250, sementara variabel Profitabilitas (ROA) meliliki median terkecil yaitu sebesar 0.043000 .

Nilai Maximum terbesar dialami oleh variabel ukuran perusahaan (SIZE) yaitu sebesar 30,40500, sementara variabel Profitabilitas (ROA) memiliki Maximum terkecil yaitu sebesar 0.227000 . Nilai Minimum terbesar dialami oleh varibel Ukuran Perusahaan (SIZE) yaitu sebesar 26,68400, sedangkan variabel Profitabilitas (ROA) memiliki nilai minimum terkecil yaitu sebesar 0.012000 .

Nilai Standar Deviasi yang terbesar dialami oleh variabel Likuiditas (LIK) yaitu sebesar 1,367287 yang berarti bahwa variabel Likuiditas memiliki tingkat risiko yang lebih tinggi mengalami perubahan dibandingkan dengan variabel-variabel yang lain selama periode penelitian. Sementara variabel Profitabilitas (ROA) mempunyai tingkat risiko lebih rendah, yaitu sebesar 0,061460. Hal ini menunjukkan bahwa variabel Profitabilitas selama periode penelitian mengalami perubahan yang tidak terlalu fluktuatif. 
Positive Skewness menunjukkan bahwa distribusi datanya memiliki ekor panjang disisi kanan dan negative skewness memiliki ekor panjang di kiri. Untuk variabel Profitabilitas (ROA) dan Likuiditas (LIK) memiliki nilai diatas 0 (nol) yang berarti bahwa asimetri distribusi data disekitar mean tidak normal, sedangkan variabel Konservatisme Akuntansi (KA), Debt Covenant (DEBT), Ukuran Perusahaan (SIZE), dan Leverage (LEVE) memiliki nilai disekitar 0 (nol) yang berrti bahwa asimetri distribusi data sekitar mean bersifat normal.

Kurtosis suatu data berdistribusi normal adalah 3. Bila kurtosis melebihi 3, maka distribusi data dikatakan leptokurtis terhadap normal. Bila kurtosis kurang dari 3, distribusi datanya datar (platykurtic) dibanding dengan data berdistribusi normal. Untuk variabel Ukuran Perusahaan (SIZE), Proftabilitas (ROA), dan Likuiditas (LIK) memiliki nilai kurtosis lebih dari 3, sementara variabel Konservatisme Akuntansi (KA), Debt Covenant (DEBT), dan Leverage (LEVE) memiliki nilai kurtosis kurang dari 3.

Jarque-Bera adalah uji statistik untuk mengetahui apakah data berdistribusi normal. Uji ini mengukur perbedaan skewness dan kurtosis data dan dibandingkan dengan apabila datanya bersifat normal. Dengan $\mathrm{HO}$ pada data berdistribusi normal, uji JaqueBera didistribusi dengan X2 dengan derajat bebas (degree of freedom) sebesar 2.

Probability menunjukkan kemungkinan nilai Jarque-Bera melebihi (dalam nilai absolut) nilai terobservasi di bawah hipotesis nol. Nilai probabilitas yang kecil cenderung mengarahkan pada penolakan hipotesis nol distribusi normal.

Pemilihan Model Regresi Data Panel

Redundant Fixed Effects

\section{Tabel 4. Uji Chow}

Tests

Equation: Untitled

Test cross-section fixed effects

\begin{tabular}{cccc}
\hline \hline Effects Test & Statistic & d.f. & Prob. \\
\hline \hline Cross-section F & 21.283447 & $(7,19)$ & 0.0000 \\
Cross-section Chi-square & 69.741777 & 7 & 0.0000 \\
\hline \hline
\end{tabular}

Sumber: data diolah, 2020

Berdasarkan tabel di atas, nilai Prob cross-section $\mathrm{F}$ dan cross-section chisquare < $(0,05)$ maka dapat disimpulkan bahwa Fixed Effect Model (FEM) lebih layak digunakan dibandingkan Common Effect Model (CEM). 
Tabel 4. Uji Hausman

Correlated Random Effects - Hausman Test

Equation: Untitled

Test cross-section random effects

\begin{tabular}{llll}
\hline \hline Test Summary & $\begin{array}{l}\text { Chi-Sq. } \\
\text { Statistic }\end{array}$ & Chi-Sq. d.f. Prob. \\
\hline \hline Cross-section random & 3.767830 & 5 & 0.5833 \\
\hline \hline
\end{tabular}

Sumber: data diolah, 2020

Berdasarkan tabel di atas, nilai Prob cross-section random $>(0,05)$ maka dapat disimpulkan bahwa Random Effect Model (REM) lebih layak digunakan dibandingkan Fixed Effect Model (FEM).

Tabel 5. Uji Lagrange Multiplier

Lagrange Multiplier Tests for Random Effects

Null hypotheses: No effects

Alternative hypotheses: Two-sided (Breusch-Pagan) and one-sided

(all others) alternatives

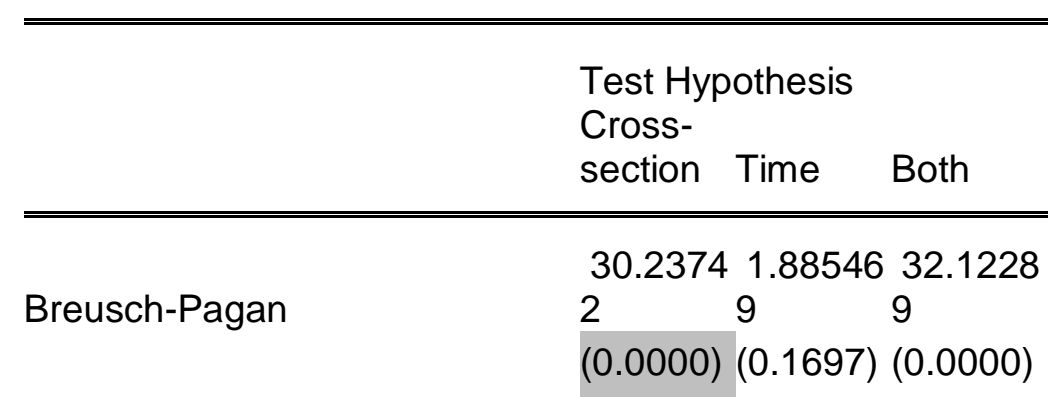

Sumber: data diolah, 2020

Berdasarkan tabel di atas, nilai Prob cross-section breusch-pagan $<(0,05)$ maka dapat disimpulkan bahwa Random Effect Model (REM) lebih layak digunakan dibandingkan Common Effect Model (CEM).

\begin{tabular}{clcc}
\multicolumn{4}{c}{ Tabel 6. Kesimpulan Data } \\
No & Metode & Pengujian & Hasil \\
1 & Uji Chow & CEM vs FEM & FEM \\
2 & Uji Hausman & REM vs FEM & REM \\
3 & Uji Lagrange & CEM vs REM & REM \\
& Multiplier & &
\end{tabular}

Berdasarkan hasil ke tiga pengujian yang sudah dilakukan maka dapat disimpulkan bahwa Model Regresi Data Panel yang akan digunakan dalam Uji Hipotesis dan Persamaan Regresi Data Panel adalah model Random Effect Model (REM), maka diperlukan Uji F dan Uji T. 


\section{Uji Hipotesis}

Dependent Variable: KA

Tabel 7. Random Effect Model

Method: Panel EGLS (Cross-section random effects)

Date: 07/04/20 Time: 19:33

Sample: 20162019

Periods included: 4

Cross-sections included: 8

Total panel (balanced) observations: 32

Swamy and Arora estimator of component variances

\begin{tabular}{|c|c|c|c|c|}
\hline Variable & $\begin{array}{l}\text { Coeffici } \\
\text { ent }\end{array}$ & $\begin{array}{l}\text { Std. } \\
\text { Error }\end{array}$ & \multicolumn{2}{|c|}{ t-Statistic Prob. } \\
\hline & \multicolumn{4}{|c|}{7.13373} \\
\hline \multirow[t]{2}{*}{ C } & 9 & \multicolumn{3}{|c|}{1.7122414 .1663180 .0003} \\
\hline & 0.38653 & & - & \\
\hline \multirow[t]{2}{*}{ DEBT } & 5 & \multicolumn{3}{|c|}{0.1618822 .3877530 .0245} \\
\hline & 0.23652 & & & \\
\hline \multirow[t]{2}{*}{ SIZE } & 5 & \multicolumn{3}{|c|}{0.0604893 .9102280 .0006} \\
\hline & 0.89916 & & - & \\
\hline \multirow[t]{2}{*}{$\mathrm{ROA}$} & 4 & \multicolumn{3}{|c|}{0.7212691 .2466420 .2236} \\
\hline & 0.01556 & & - & \\
\hline LIK & $\begin{array}{l}1 \\
0.10348\end{array}$ & \multicolumn{3}{|c|}{0.0216920 .7173740 .4795} \\
\hline \multirow[t]{3}{*}{ LEVE } & 0 & \multicolumn{3}{|c|}{0.0664451 .5573740 .1315} \\
\hline & $\begin{array}{l}\text { Effects } \\
\text { Specific }\end{array}$ & sation & & \\
\hline & & & S.D. & Rho \\
\hline \multirow[t]{2}{*}{$\begin{array}{l}\text { Cross-section random } \\
\text { Idiosyncratic random }\end{array}$} & & & \multicolumn{2}{|c|}{$\begin{array}{l}0.2364430 .9455 \\
0.0567660 .0545\end{array}$} \\
\hline & \multicolumn{4}{|c|}{$\begin{array}{l}\text { Weighted } \\
\text { Statistics }\end{array}$} \\
\hline R-squared & $\begin{array}{l}0.49243 \\
4 \\
0.39482\end{array}$ & $\begin{array}{l}\text { Mear } \\
\text { depend } \\
2 \quad \text { S.D. }\end{array}$ & $\begin{array}{l}\text { nt var } \\
\text { dependen }\end{array}$ & 0.033052 \\
\hline Adjusted R-squared & $\begin{array}{l}5 \\
0.05540\end{array}$ & var Sum & squareo & 0.071221 \\
\hline S.E. of regression & $\begin{array}{l}5 \\
5.04497\end{array}$ & $\begin{array}{l}\text { resid } \\
\text { Durb }\end{array}$ & n-Watson & 0.079812 \\
\hline $\begin{array}{l}\text { F-statistic } \\
\text { Prob(F-statistic) }\end{array}$ & $\begin{array}{l}6 \\
0.00231\end{array}$ & stat & & 1.309274 \\
\hline
\end{tabular}


1

\begin{tabular}{|c|c|c|}
\hline & $\begin{array}{l}\text { Unweighted } \\
\text { Statistics }\end{array}$ & \\
\hline R-squared & $\begin{array}{l}0.23420 \text { Mean } \\
3 \quad \text { dependent var } \\
0.90105 \quad \text { Durbin-Watson }\end{array}$ & 0.277313 \\
\hline Sum squared resid & 7 stat & 0.115970 \\
\hline
\end{tabular}

Sumber : data diolah, 2020

Berdasarkan hasil tabel Random Effect Model (REM) yang ditampilkan pada tabel diatas menunjukkan bahwa nilai Fstatistic sebesar 5,044976, sementara $F$ Tabel dengan tingkat $\alpha=5 \%$, df1 $(k-1)=5$ dan df2 $(n-k)=26$ didapat nilai $F$ Tabel sebesar 2.58679. Dengan demikian F-statistic $(5,044976)>$ F Tabel (2.58679) dan nilai Prob(Fstatistic) $0.002311<0,05$ maka dapat disimpulkan bahwa Ha diterima, yang artinya variabel variabel independen dalam penelitian ini yang terdiri dari Debt Covenant, Ukuran Perusahaan, Profitabilitas, Likuiditas dan Leverage secara bersama-sama memiliki pengaruh terhadap Konservatisme Akuntansi.

Berdasarkan hasil tabel Random Effect Model (REM) yang ditampilkan pada tabel diatas menunjukkan bahwa, nilai Adjusted $R$-squared sebesar 0,394825, artinya bahwa variasi perubahan naik turunnya Konservatisme Akuntansi dapat dijelaskan oleh Debt Covenant, Ukuran Perusahaan, Profitabilitas, Likuiditas dan Leverage sebesar 39,4 persen, sementara sisanya yaitu sebesar 60,6 persen dijelaskan oleh variabel - variabel lain yang tidak diteliti dalam penelitian ini.

Dari hasil yang ditampilkan pada tabel diatas menunjukan bahwa hasil uji t Debt Covenant, Ukuran Perusahaan, Profitabilitas, Likuiditas dan Leverage terhadap Konservatisme Akuntansi adalah sebagai berikut:

a. Nilai $t$-statistic Debt Covenant (DEBT) sebesar $-2,387753$, sementara $\mathrm{t}$ Tabel dengan tingkat $\alpha=5 \%$, df $(n-k)=26$ didapat nilai t Tabel sebesar 2,055529 . Dengan demikian $t$-statistic Debt Covenant $(-2,387753)<\mathrm{t}$ Tabel $(2,58679)$ dan nilai Prob. 0,0245<0,05 maka dapat disimpulkan bahwa variabel Debt Covenant dalam penelitian ini memiliki pengaruh terhadap Konservatisme Akuntansi. Dengan demikian, $\mathrm{H} 1$ dalam penelitian ini diterima.

b. Nilai $t$-statistic Ukuran Perusahaan (SIZE) sebesar -3,910228. Sementara $\mathrm{t}$ Tabel dengan tingkat $\alpha=5 \%$, df $(n-k)=26$ didapat nilai $t$ Tabel sebesar 2,055529. Dengan demikian t-statistic SIZE ($3,910228)<\mathrm{t}$ Tabel $(2,055529)$ dan nilai Prob 0,0006 < 0,05 maka dapat disimpulkan bahwa variabel Ukuran Perusahaan dalam penelitian ini memiliki pengaruh terhadap Konservatisme Akuntansi. Dengan demikian, $\mathrm{H} 2$ dalam penelitian ini diterima. 
c. Nilai $t$-statistic Provitabilitas (ROA) sebesar -1,246642. Sementara $t$ Tabel dengan tingkat $\alpha=5 \%$, df $(n-k)=26$ didapat nilai t Tabel sebesar 2,055529. Dengan demikian $t$-statistic ROA $(-1,246642)<\mathrm{t}$ Tabel (2,055529) dan nilai Prob. 0,2236 > 0,05 maka dapat disimpulkan bahwa variabel Profitabilitas dalam penelitian ini tidak memiliki pengaruh terhadap Konservatisme Akuntansi. Dengan demikian, H3 dalam penelitian ini ditolak.

d. Nilai $t$-statistic Likuiditas sebesar -0,717374. Sementara t Tabel dengan tingkat $\alpha=5 \%$, df $(n-k)=26$ didapat nilai $t$ Tabel sebesar 2,055529. Dengan demikian $t$-statistic Likuiditas $(-0,717374)<\mathrm{t}$ Tabel $(2.055529)$ dan nilai Prob. 0,4795 > 0,05 maka dapat disimpulkan bahwa variabel Likuiditas dalam penelitian ini memiliki tidak memiliki pengaruh terhadap Konservatisme Akuntansi. Dengan demikian, H4 dalam penelitian ini ditolak.

e. Nilai $t$-statistic Leverage sebesar 1,557374. Sementara t Tabel dengan tingkat $\alpha=5 \%$, df $(n-k)=26$ didapat nilai $t$ Tabel sebesar 2,055529. Dengan demikian $t$-statistic Leverage $(1,557374)<\mathrm{t}$ Tabel $(2,055529)$ dan nilai Prob. 0,1315 > 0,05 maka dapat disimpulkan bahwa variabel Leverage dalam penelitian ini tidak memiliki pengaruh terhadap Konservatisme Akuntansi. Dengan demikian, H5 dalam penelitian ini ditolak.

Hasil persamaan regresi yang diperoleh adalah :

$$
\begin{gathered}
Y=7,133739-0,386535 X_{1}-0,236525 X_{2^{-}} \\
0,899164 X_{3}-0,015561 X_{4}+0,103480 X_{5}+\varepsilon
\end{gathered}
$$

Persamaan regresi diatas memiliki makna sebagai berikut:

a. Nilai konstanta $=7,133739$ bernilai positif. Hal ini mengindikasikan bahwa jika variabel Debt Covenant, Ukuran Perusahaan, Profitabilitas, Likuiditas, Leverage sama dengan nol (0) atau konstan, maka variabel Konservatisme Akuntansi akan meningkat sebesar 7,133739.

b. Nilai koefisien regresi variabel Debt Covenant negative sebesar 0,386535. Hal ini berarti apabila Debt Covenant mengalami penurunan sebesar satu satuan, maka diikuti peningkatan koefisien Konservatisme Akuntansi sebesar -0,386535, dengan asumsi variabel lainnya konstan.

c. Nilai koefisien regresi variabel Ukuran Perusahaan (SIZE) negative sebesar -0,236525 artinya apabila ukuran perusahaan mengalami penurunan sebesar satu satuan, maka diikuti peningkatan koefisien konservatisme akuntansi sebesar $-0,236525$, dengan asumsi variabel lainnya konstan.

d. Nilai koefisien regresi variabel Profitabilitas (ROA) negative sebesar 0,899164 . Hal ini berarti apabila Prifitabilitas mengalami penurunan sebesar satu satuan, maka diikuti peningkatan koefisien konservatisme akuntansi sebesar -0,899164, dengan asumsi variabel lainnya konstan. 
e. Nilai koefisien regresi variabel Likuiditas negative sebesar -0,015561. Hal ini berarti apabila Likuiditas mengalami penurunan sebesar satu satuan, maka diikuti peningkatan koefisien konservatisme akuntansi sebesar -0,015561, dengan asumsi variabel lainnyya konstan.

f. Nilai koefisien regresi variabel Leverage positif sebesar 0,103480. Hal ini berarti apabila Leverage mengalami peningkatan sebesar satu satuan, maka akan diikuti peningkatan koefisien konservatisme akuntansi sebesar 0,103480dengan asumsi variabel lainnya konstan.

Interpretasi Hasil

Berdasarkan uji t (parsial) maka dapat disimpulkan bahwa variabel Debt Covenant dalam penelitian ini memiliki pengaruh terhadap Konservatisme Akuntansi. Hal tersebut berarti semakin rendah nilai debt covenant perusahaan maka tingkat konservatifnya semakin meningkat. Hasil penilitian ini tidak sejalan dengan penilitian yang dilakukan oleh Susanto dan Ramadhani (2016), Tosi dan Paidar (2015) yang menyatakan Debt Covenant tidak memiliki pengaruh terhadap konservatisme akuntansi.

Berdasarkan uji t (parsial) variabel Ukuran Perusahaan dalam penelitian ini memiliki pengaruh terhadap Konservatisme Akuntansi. Semakin besar Ukuran Perusahaan maka semakin konservatif perusahan tersebut. Hasil penelitian ini mendukung penelitian Sari dan Adhariani (2009) bahwa ukuran perusahaan berpengaruh signifikan terhadap tingkat konservatisme akuntansi.

Berdasarkan uji t (parsial) variabel Profitabilitas dalam penelitian ini tidak memiliki pengaruh terhadap Konservatisme akuntansi. Besar kecilnya profitabilitas tidak akan mempengaruhi peringkat obligasi perusahaan di masa mendatang. Hasil penelitian ini sejalan dengan penelitian Susilowati dan Sumarto (2010) serta Almilia dan Devi (2007).

Berdasarkan uji t (parsial) variabel Likuiditas dalam penelitian ini tidak memiliki pengaruh terhadap Konservatisme Akuntansi. Karena pada dasarnya likuiditas berhubungan dengan kepercayaan para kreditor kepada perusahaan, artinya semakin tinggi likuiditas maka semakin tinggi pula kepercayaan para kreditor terhadap perusahaan sehingga perusahaan secara otomatis akan menjaga kinerja perusahaan agar tetap mendapat kepercayaan kreditor. Hasil penelitian ini didukung oleh Hardinsyah (2013) yang menyatakan likuiditas tidak berpengaruh terhadap konservatisme.

Berdasarkan uji t (parsial) variabel Leverage dalam penelitian ini tidak memiliki pengaruh terhadap Konservatisme Akuntansi. Hal ini menunjukan jika perusahaan mempunyai hutang yang tinggi atau rendah tidak akan menjadikan perusahaan semakin konservatif karena kemungkinan perusahaan akan selalu menggunakan prinsip konservatisme untuk menghadapi keadaan yang tidak pasti sehingga tinggi rendahnya tingkat hutang tidak akan mempengaruhi konservatisme. Hasil ini bertentangan dengan peneliti Lo (2005). 


\section{KESIMPULAN}

Berdasarkan hasil pembahasan atas pengujian hipotesis mengenai pengaruh Debt Covenant terhadap Konservatisme, didapatkan hasil uji tstatistic $<-$ ttabel $(-2,387753<2,58679)$ dengan Tingkat signifikansi 0,0245 lebih kecil dari 0,05. Sehingga dapat disimpulkan bahwa secara parsial variabel Debt Covenant berpengaruh negative signifikan terhadap variabel Konservatisme.

Berdasarkan hasil pembahasan atas pengujian hipotesis mengenai Ukuran Perusahaan terhadap Konservatisme, didapatkan hasil uji tstatistic < - ttabel $(-3,910228<2,58679)$ dengan tingkat signifikansi 0,0006 lebih kecil dari 0,05. Sehingga dapat disimpulkan bahwa secara parsial variabel Ukuran Perusahaan berpengaruh negative namun signifikan terhadap variabel Konservatisme.

Berdasarkan hasil pembahasan atas pengujian hipotesis mengenai pengaruh Profitabilitas terhadap Konservatisme, didapatkan hasil uji tstatistic < ttabel $(-1,246642<2,58679)$ dengan tingkat signifikansi 0,2236 lebih besar dari 0,05 . Sehingga dapat disimpulkan bahwa secara parsial variabel Profitabilitas tidak berpengaruh dan tidak signifikan terhadap variabel Konservatisme.

Berdasarkan hasil pembahasan atas pengujian hipotesis mengenai pengaruh Likuiditas terhadap Konservatisme, didapatkan hasil uji tstatistic $<$ ttabel $(-0,717374<2,58679)$ dengan tingkat signifikansi 0,4795 lebih besar dari 0,05. Sehingga dapat disimpulkan bahwa secara parsial variabel Likuiditas tidak berpengaruh dan tidak signifikan terhadap variabel Konservatisme.

Berdasarkan hasil pembahasan atas pengujian hipotesis mengenai pengaruh Leverage terhadap Konservatisme, didapatkan hasil uji tstatistic < ttabel $(1,557374<2,58679)$ dengan tingkat signifikansi 0,1315 lebih besar dari 0,05. Sehingga dapat disimpulkan bahwa secara parsial variabel Leverage tidak berpengaruh secara signifikan terhadap variabel Konservatisme.

\section{DAFTAR PUSTAKA}

Sari, D. N. (2014). Pengaruh Struktur Kepemilikan Institutional, Struktur Kepemilikan Manajerial, Struktur Kepemilikan Publik, Debt covenant dan Growth Opportunities Terhadap Konservatisme Akuntansi. 1(2), $1-15$.

Iskandar, O.I. (2010). PENGARUH DEBT COVENANT, BONUS PLAN, DAN POLITICAL COST TERHADAP KONSERVATISME AKUNTANSI. https://doi.org/10.34209/equ.v22i1.896

Noviantari, N., \& Ratnadi, N. (2015). Pengaruh Financial Distress, Ukuran Perusahaan, Dan Leverage Pada Konservatisme Akuntansi. E-Jurnal Akuntansi, 11(3), 646-660.

Oktavia, M., Sinambela, E., \& Spica, L. (2018). Faktor-faktor yang mempengaruhi konservatisme akuntansi. 21(2), 289-312. 
Pratanda. (2014). Terhadap, D A N Leverage Akuntansi, Konservatisme. 3(2), 255-263.

Perusahaan, P. U., Leverage, R., Modal, I., Perusahaan, D. A. N. L., H, W. P., Akuntansi, J., Ekonomika, F., \& Diponegoro, U. (2013). ( Studi pada Perusahaan yang Belum Menggunakan IFRS ). 2, 1-11.

Suharni, S., Wildaniyati, A., \& Andreana, D. (2019). Pengaruh Jumlah Dewan Komisaris, Leverage , Profitabilitas , Intensitas Modal , Cash Flow, Dan Ukuran Perusahaan Terhadap Konservatisme ( Studi Empiris Pada Perusahaan Manufaktur Yang Terdaftar Di Bursa Efek Indonesia Tahun 2012-2017). 8, 17-24.

Susilo, T. P. (2013). Opportunities, dan Profitabilitas Terhadap Konservatisme Akuntansi. 4-21. 